\title{
Exploring the notion of a 'capability for uncertainty' and the implications for leader development
}

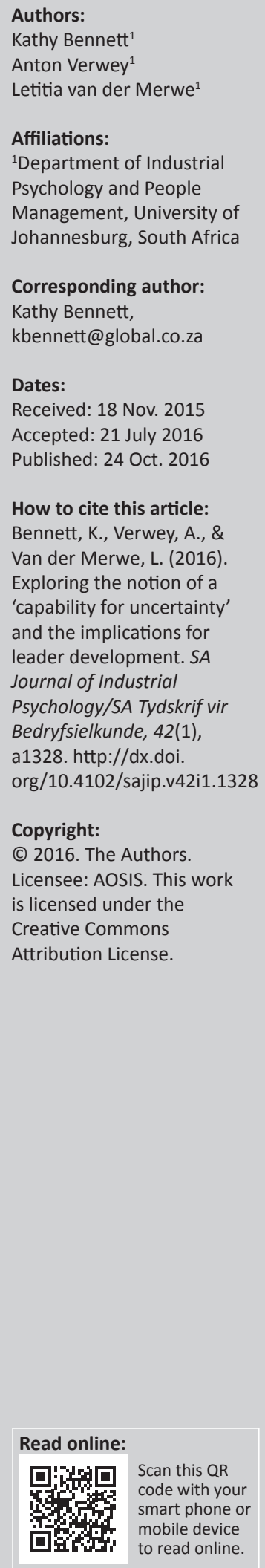

Authors:

Kathy Bennett ${ }^{1}$

Affiliations:

Department of Industria Management, University of Johannesburg, South Africa

Corresponding author: Kathy Bennett,

Dates:

Accepted: 21 July 2016

How to cite this article:

Exploring the notion of a

'capability for uncertainty'

Journal of Industrial

Psychology/SA Tydskrif vir

1328. http://dx doi.

org/10.4102/sajip.v42i1.1328

Copyright:

Licensee: AOSIS. This work

is licensed under the

Creative Commons

mobile device

to read online.
Orientation: With uncertainty increasingly defining organisational contexts, executive leaders need to develop their 'capability for uncertainty' - the ability to engage with uncertainty in their organisational context and to lead others, while simultaneously managing their own experience of uncertainty. However, what constitutes such a holistic 'capability for uncertainty' is not clear.

Research purpose: The purpose was to gain an understanding of what constitutes a capability for uncertainty.

Motivation for the study: Gaining an understanding of what components constitute leaders' capability for uncertainty would provide a basis for determining what interventions would be relevant for developing leaders towards achieving such a capability.

Research approach, design and method: An interpretive qualitative approach was adopted, using interpretative phenomenological analysis to gain an understanding of what capability executive leaders developed through their lived experience of uncertainty. Two purposive samples of six executive leaders from two different South African companies (a private company and a state-owned company), which had both been experiencing long-term organisational uncertainty prior to and up to the time of the study, were used. Data were collected through semi-structured interviews.

Main findings: The executives all developed their capability for uncertainty through lived experiences of uncertainty, to a greater or lesser extent. Five components were identified as constituting a holistic capability for uncertainty, as follows: a sense of positive identity, an acceptance of uncertainty, effective sense-making, learning agility and relevant leadership practices during organisational uncertainty.

Practical/managerial implications: Organisations need to target and design leader development interventions to specifically develop these components of a holistic capability for uncertainty in executives and leaders, enabling them to engage more effectively with uncertainty and to more positively manage their experience of uncertainty in these increasingly turbulent times.

Contribution/value-add: The key contribution is the identification of five crucial components constituting a capability for uncertainty, which can be used to inform leadership development interventions designed to develop such capability in leaders.

\section{Introduction}

To facilitate the development of leaders, with the specific purpose of increasing their effectiveness in times of increasing organisational uncertainty, research is required to understand what a capability for uncertainty is - and what specific components constitute such a capability.

Although turbulence in the environment of the private and public sectors is not a new phenomenon, the scale of turbulence being experienced globally is unprecedented compared to previous generations (Cavanagh \& Lane, 2012). This increasing turbulence is attributed to globalisation, innovation in information technology, market volatility, increased regulation and diverse stakeholder expectations (Axon, Friedman \& Jordan, 2015; Lane \& Down, 2010). The significance of this turbulence for leaders is that continuous adaptation and change result in ongoing uncertainty in their organisational contexts, such as new strategies, technological innovation and re-structuring (Lane \& Down, 2010; White \& Shullman, 2010). Individuals and leaders then, in turn, experience uncertainty (Brashers, 2001). In research after the global financial crisis of 2008, Day and Power (2009) found that the context of uncertainty in organisations fostered experienced 
uncertainty for executive leaders (members of the top management team), manifesting mostly as doubt and anxiety in needing to make sense of what was happening and the business implications thereof. They also experienced pressure from multiple stakeholders to account for what was going on, including dealing with their employees' anxiety and need for reassurance.

The environmental challenges of turbulence and resulting contexts of organisational uncertainty are therefore creating new demands for leadership capabilities (Axon et al, 2015; Day, 2011; DeRue \& Myers, 2013; Petrie, 2011). Executive leaders need to set the tone for how uncertainty is approached in their organisations (Akrivou \& BradburyHaung, 2011). They therefore need to develop their capability for uncertainty, defined in this study as the ability to engage with uncertainty in their organisational context and to lead others, while simultaneously managing their own experienced uncertainty. Day and Power (2009, p. 25) suggest that such a capability for uncertainty 'is more likely to develop through experiential learning which evolves from life experience and processes such as action learning, executive coaching and business simulation', thus requiring relevant and focussed leader development interventions.

What constitutes a holistic capability for uncertainty, however, is not clear, thus requiring research (Lane \& Klenke, 2004; Woods, Gapp, King \& Fisher, 2013). Of relevance, Buckle (2009) found that Human Resources sponsors of executive coaching, in organisations based in the United Kingdom, were not clear about the purposes of coaching in relation to developing leaders' capability for uncertainty, as they had difficulty in articulating what leaders specifically needed to develop. Thus, the notion of 'a capability for uncertainty' needs to be understood as the basis for determining what development interventions would be required for developing such capability in leaders. There is consensus that the key source of leadership development is experience (DeRue \& Ashford, 2010a; McCall, 2010), particularly the development of a capability for uncertainty, which requires learning through and from the experience of uncertainty (Day \& Power, 2009; Hase, 2002, p. 3). Therefore, research focussing on what capability for uncertainty executive leaders developed from their lived experience of uncertainty would provide valuable insights for accelerating development of this capability in leaders (Woods et al., 2013).

\section{Research purpose and research objective}

From the background sketched above, the problem is that there is limited knowledge of and a paucity of research on what constitutes a capability for uncertainty (Buckle, 2009; Lane \& Klenke, 2004; Woods et al., 2013) to inform leader development interventions required for developing such a capability. Hence, the research purpose was to gain an understanding of what constitutes a holistic capability for uncertainty. The research objective was to understand what capability executive leaders developed through their lived experience of uncertainty towards clarifying what components constitute a capability for uncertainty.

\section{Literature review}

\section{The concept and nature of uncertainty}

There are varying definitions of uncertainty in the literature across different disciplines, making it difficult to define the construct of uncertainty (Smithson, 2008b; Van den Bos \& Lind, 2009). Brashers (2001, p. 481) cautioned one to be cognisant of uncertainty as being multi-layered and interconnected, particularly within an organisational context, which is the setting for this study. In essence, personal or experienced uncertainty is seen to be a complex and dynamic, cognitive-affective phenomenon, triggered by different and multiple sources in oneself and in one's context (Brashers, 2001; Smithson 2008b).

Therefore, the meaning of uncertainty in this study requires a psychological perspective, which acknowledges that personal or experienced uncertainty is at the interface between the individual and the individual's context, as advocated by Arkin, Oleson and Carroll (2010) in their meta-review of research on self-uncertainty. They positioned the construct of personal or subjective uncertainty as encompassing both personality psychology (related to the individual's predispositions) and social psychology (related to the context and relationships the individual is situated in). Experienced or personal uncertainty, the key focus of this study, may be triggered by situations or events in one's context, which challenge an individual's perceptions, beliefs and sense of self or identity (Hogg, 2009). The definition of experienced uncertainty used in this study, informed by that of Arkin et al. (2010, p. 8), is a personal or subjective uncertainty manifesting as feeling unsure about the self and one's context, as well as the inter-relationship between them, where context refers to the organisational environment.

\section{The meaning of a capability for uncertainty}

The need for developing leaders' capability for uncertainty was outlined in the introduction to this paper. A capability for uncertainty was defined for this study as leaders' ability to engage with uncertainty in their organisational context and to lead others, while simultaneously managing their own experienced uncertainty. When considering leader development, a distinction needs to be made between 'capability' and 'competency', terms which are often used inter-changeably (Woods et al., 2013). Competencies are related to specific skills and knowledge required to develop proficiency in an individual's job to a required standard (Woods et al., 2013). Turning to capability, some theorists emphasise capability as being an individual's innate potential in the future (Brown \& McCartney, 2003; Jacques, 1989), with cognitive complexity being stressed as a key indicator of such potential by Jacques (1989).

The meaning of 'capability', which informs this study, is different. This notion of capability, rooted in an education and training perspective, emerged in the United Kingdom during the mid-1980s as a response to the increasing degree 
of change and uncertainty in the world and the workplace. Authors informed by this perspective (Hase, 2002; Phelps, Hase \& Ellis, 2005) suggest that 'capable' people are those who know how to learn in a self-directed way, have a high degree of self-efficacy, work well with others and can apply competencies in novel, unfamiliar situations. Such capability is defined as a 'holistic attribute' enabling people to 'deal with the turbulent environment in which they live (or work)' (Gardner, Hase, Gardner, Dunn \& Carryer, 2007, p. 252).

Therefore, developing individual capability requires different learning experiences, with an emphasis on learning through and from experience (Hase, 2002, p. 3). Thus, capability seems to develop through the interaction of individuals with their context and is more about 'becoming' through experience over time (Phelps et al., 2005, p. 69). Research is essential to understand what comprises individual capability, how it is enacted and how it is developed in different contexts over time to provide empirical support for the construct of capability, as argued by Woods et al. (2013), which was the focus of this study.

\section{Crucial components for developing a capability for uncertainty}

The literature review has revealed different concepts and components, which seem to be crucial for developing leaders' capability for uncertainty, as outlined below.

A tolerance for and acceptance of uncertainty: The limited research on executives' experience of uncertainty established the importance of being able to tolerate uncertainty in order to cope with or engage with the uncertainty (Buckle, 2009; Day \& Powers, 2009). In personality trait research, one's uncertainty response is seen to be related to an individual's predisposition to tolerate ambiguity (Budner, 1962) or one's personal orientation to uncertainty (Greco \& Roger, 2001; Sorrentino \& Roney, 2000; Szeto \& Sorrentino, 2010). This approach has been criticised because an individual's uncertainty orientation might vary for situational events within and across different contexts, and the relevance of applying a one-dimensional continuum to the cognitiveaffective complexity of uncertainty orientation has been questioned (Smithson, 2008b). White and Shullman (2010) have argued that an acceptance for uncertainty can be developed through experience and over time, as found by Bennis and Thomas (2002).

Learning agility: On-the-job development through experience was perceived by successful executives to be the most significant form of leadership development (McCall, Lombardo \& Morrison, 1988). The lessons learned from the executives' experiences were what contributed to their development. However, people differ in their ability to learn from experience (McCall et al., 1998). Those who adopt a self-directed approach to their learning have the openness and willingness to learn from experience (DeRue \& Ashford, 2010a; Kolb, 1984; McCall, 2010). Hence, learning agility means the ability and willingness to learn from experience and to subsequently apply or adapt that learning to perform effectively in novel contexts or situations (Lombardo \& Eichinger, 2000, 2002). The concept of learning agility has been expanded to include other attributes such as eagerness to learn (about self, others and ideas) and resilience (Lombardo \& Eichinger, 2002).

Critical reflection: Reflection is crucial for extracting learning from experience (DeRue \& Ashford, 2010a; Kolb, 1984; Mezirow, 2001). For transformative learning to occur, such as gaining a new perspective and/or an altered sense of identity, Mezirow (2001) suggested that it would depend on the leader's capacity for more critical reflection about unquestioned assumptions or perspectives for meaningful insight to occur (Argyris \& Schon, 1996; Mezirow, 2001). While critical reflective learning is seen to be essential for leaders (Day, Harrison \& Halpin, 2009; Petrie, 2011; Schwandt, 2005), most leaders do not have time or make time for reflection (Day et al., 2009; DeRue \& Ashford, 2010a; Parry, 2003). In times of adversity, leaders may resort to rumination, a form of maladaptive reflection (Hannah \& Avolio, 2010). Therefore, constructive critical reflection is an effortful process requiring emotional regulation, and dialogue with another person (Brockbank \& McGill, 2006; DeRue \& Ashford, 2010a).

Effective sense-making: Sense-making involves generating a plausible and coherent account of what is going on through iterative processes of information gathering, conversations, thinking and actions (Maitlis \& Christianson, 2014; Weick, Sutcliffe \& Obstfeld, 2005). More explicit and effortful sensemaking is energised when a disruption or uncertainty is experienced in one's context (Weick, 1995; Weick et al., 2005). However, because uncertainty usually triggers emotions, and sense-making tends to rely on one's current mental frames, effective sense-making does not always occur (Maitlis, Vogus \& Sonnenshein, 2013; Schwandt, 2005). Intense emotions induced by anxiety or perceived threat, when effective sense-making is most required, often leads to counter-productive behaviour (Ancona, 2011; Maitlis et al., 2013), such as rigidity, withdrawal or over-reaction. Consequently, leaders need to engage others in their sensemaking to broaden their range of sense-making frames (Ancona, 2011) and they must challenge their own mental frames through critical reflection (Schwandt, 2005).

A sense of positive identity: A 'new or altered sense of identity' was found to be associated with adaptive capacity developed through leaders' crucibles of experience, which also equipped them for future crucibles (Bennis \& Thomas, 2002 , p. 63). The construction of a positive identity appears to foster a form of individual 'strengthening' defined as 'increasing an individual's capacity to endure stress and hardship and/or increasing their capacity to take on new demands and challenges' (Dutton, Roberts \& Bednar, 2010, p. 275). This strengthening occurs because a positive identity builds more social resources or relationships that one has access to, leading to other resources such as trust and information (Dutton et al., 2010, p. 266). A positive leader identity, reflected in confidence, credibility and reputation, 
facilitates leader effectiveness, particularly in uncertain contexts, by building trust in others and by being more confident in one's leadership approach, purpose and values (Day et al., 2009; Karp \& Helgo, 2009). However, leader identity construction is increasingly viewed as being rooted in a social process of negotiation with and recognition by key stakeholders (Karp \& Helgo, 2009; Sinclair, 2011), meaning that it may not be accomplished by individuals in certain contexts (Day et al., 2009).

Leadership during organisational uncertainty: Developing executive leaders' capability for uncertainty also needs to take into account the challenges they face in their leadership role during organisational uncertainty - and relevant approaches for dealing with them.

Firstly, research has identified the 'increased level of complexity and inter-connectedness' as a key challenge for leaders (Petrie, 2011, p. 8). Beautement and Broenner (2011) distinguish between contextual complexity or objective complexity in one's context, versus experienced complexity, which is subjectively experienced by people, such as feeling overwhelmed. Given that executives are dealing with increasing contextual complexity in these turbulent times (Petrie, 2011), one can expect a corresponding increase in their subjective, experienced complexity. Thus, being able to come to terms with both being in control and not in control is essential for executives experiencing complexity (Karp \& Helgo, 2008; Lane \& Down, 2010; Simpson, 2012; Snowden \& Boone, 2007).

Secondly, a key challenge for executive leaders is effectively influencing multiple and diverse stakeholders (Buckle, 2009) through networking, negotiating and resolving conflicts all of which require political skill (Ashraf \& Iqbal, 2011). However, politics has a negative connotation and a perceived dysfunctional side to it (Ashraf \& Iqbal, 2011; Buchanan, 2008). Yet some authors argue that political skill can generate positive consequences for individuals and organisations and is even necessary and valuable in the context of organisational change (Buchanan \& Badham, 2011), implying a positive side to politics. Consequently, leaders need to understand political dynamics and be able to exercise appropriate political expertise (Goffee \& Jones, 2009; Heifetz, Grashow \& Linsky, 2009).

Thirdly, leading others during organisational uncertainty is a key challenge for leaders. There is consensus that executive leaders need to view organisations as complex adaptive systems, that is, to see organisations as complex systems comprising inter-related parts, having emergent properties, able to self-organise and be adaptive to changes in their environment (Kurtz \& Snowden, 2003; Obolensky, 2010; Stacey, 1996). Therefore, executives need to adopt an enabling leadership approach to foster adaptive capacity within their organisations (Uhl-Bien, Marion \& McKelvey, 2007). They must facilitate conditions for allowing emergence of conversation, collaboration and self-organising potential, which then translates into adaptive capacity of the organisation, essential for adjusting to the turbulent environment (Heifetz et al., 2009; Lane \& Down, 2010).

Executive leaders need to be flexible in blending their leadership approach to shifting degrees of complexity within their organisations and environments (Obolensky, 2010; Snowden \& Boone, 2007). Executives need to be able to make sense of the context and to articulate meaning or sense-giving for others (Akrivou \& Bradbury-Haung, 2011; Goffee \& Jones, 2009). This means providing a vision, giving sufficient direction, clarifying boundaries and what to focus on (Goffee \& Jones, 2009; Heifetz et al., 2009; Snowden \& Boone, 2007). Importantly, while leaders cannot give certainty, they can instil confidence and hope (Day \& Power, 2009; Smerek, 2011). Yet, there is a strong argument for leaders to be authentic and genuine in these times (Avolio \& Gardner, 2005). Hence, a paradox presents for many leaders when feeling personal uncertainty, in believing they need to communicate calm and optimism to people (Bunker, 2010; Heifetz et al., 2009). Finding the balance between being empathetic, genuine (showing appropriate emotion) and engaging people in their anxiety, while leading the change positively, is therefore required (Bunker, 2010; Heifetz et al., 2009).

\section{Research design \\ Research approach}

The research study was exploratory, adopting Interpretative Phenomenological Analysis (IPA), which falls within a qualitative, interpretivist research paradigm. IPA is a suitable approach for exploring individuals' experience of a specific phenomenon and how they make sense or meaning of it (Smith, 2011). In this study, the focus was on executives making sense (retrospectively) of how they developed through their lived experience of uncertainty. IPA is both phenomenological and inductive, by rooting the findings in participants' lived experience of the phenomenon studied (Smith, Flowers \& Larkin, 2009). It is interpretative as 'the researcher attempts to interpret how the participants make sense of their experience' (Pringle, Drummond, McLafferty \& Hendry, 2011, p. 20). IPA is also idiographic, meaning that it highlights the nuance of variation experienced by different participants (Smith, 2011).

\section{Research strategy}

The research strategy was cross-sectional and retrospective (Bryman \& Bell, 2003), comprising two samples of executive leaders from two South African companies, which had been experiencing organisational change and uncertainty in their contexts - prior to and up to the time of the study. Being idiographic, the primary unit of analysis was the individual (Willig, 2008). After analysis of the individual executives' data, collected through single interviews with them, patterns of similarity and instances of variance across the individuals within each sample were identified (Smith et al., 2009). The findings from these two samples were then integrated to give a richer account of executive leader's 
TABLE 1: The context of organisational change and uncertainty in each company.

\begin{tabular}{|c|c|c|}
\hline Feature & Company R (private company) & Company P (state-owned company) \\
\hline Duration of organisational change and uncertainty & Five years of organisational uncertainty. & Eighteen months of organisational uncertainty. \\
\hline Key trigger for period of organisational uncertainty & A change of ownership since 2007. & The secondment of the Managing Director (MD) to The City. \\
\hline \multirow[t]{2}{*}{$\begin{array}{l}\text { Organisational changes and events over period of } \\
\text { uncertainty }\end{array}$} & $\begin{array}{l}\text { Previously owned by an international organisation, which } \\
\text { entered into a black empowerment deal in South Africa, } \\
\text { resulting in the change of ownership and a large financial } \\
\text { debt to be paid off by Company R. }\end{array}$ & $\begin{array}{l}\text { The secondment became a permanent appointment, } \\
\text { resulting in an 18-month period of various acting MDs and } \\
\text { executives, as an interim measure until a new MD was } \\
\text { appointed. }\end{array}$ \\
\hline & $\begin{array}{l}\text { There were changes in the executive team (including new } \\
\text { people in acting roles), changes in the Board, increased } \\
\text { competition in their market and extreme financial pressures } \\
\text { because of debt incurred by the change of ownership deal - } \\
\text { and the global financial crisis of } 2008 \text {. }\end{array}$ & $\begin{array}{l}\text { There were changes in the executive team, changes in the } \\
\text { management of The City (as a result of municipal elections) } \\
\text { and the company's Board. Political pressures (because of } \\
\text { politicians' agendas in The City structure), changes in The } \\
\text { City's management approach and financial constraints added } \\
\text { to the uncertainty. }\end{array}$ \\
\hline
\end{tabular}

development from the lived experience of uncertainty across two different organisational contexts and different time periods of uncertainty.

\section{Research method}

\section{Research setting}

The research setting was the organisational context in South Africa. The study involved executive leaders in two different companies who had experienced organisational uncertainty in their contexts - prior to and up to the time of the study, as depicted in Table 1. One was a private company (Company R) in the manufacturing sector, and the other was a state-owned company (Company P) being a utility service provider owned by a major city, referred to as 'The City'.

Both companies had individuals transitioning into and out of their executive committees during their respective periods of uncertainty and they also had different leadership development initiatives during these periods. These were variables that could not be controlled for as they formed part of their organisational contexts, adding to the reality and dynamics of the uncertainty being experienced, an essential feature of qualitative inquiry (Henning, van Rensburg \& Smit, 2004).

Entrée and establishing researcher role: The researcher gained access to the above research settings using her own professional network, through an identified gatekeeper for each company in the Human Resources function. Permission was first obtained from the Chief Executive Officer of Company $\mathrm{R}$ and the Managing Director of Company $\mathrm{P}$, with the proviso that the companies and the individual participants remain anonymous. The researcher was the main instrument for collecting the data through interviews (Henning et al., 2004) and then interpreting the data, in the tradition of IPA (Willig, 2008).

\section{Research participants and sampling methods}

As IPA focusses on small, fairly homogeneous samples based on having the lived experience of the phenomenon being investigated (Willig, 2008), purposive sampling was used. Convenience sampling played a role in gaining access to suitable participants (Smith et al., 2009). The key sampling criterion was executive leaders in companies that had been experiencing change and uncertainty in their organisational contexts prior to and up to the time of data collection.

\begin{tabular}{|c|c|c|c|c|c|}
\hline Company & Executive role & Age & Gender & Race & $\begin{array}{c}\text { Executive } \\
\text { experience } \\
\text { (years) }\end{array}$ \\
\hline \multirow[t]{6}{*}{$\mathrm{R}$} & Commercial & 49 & Male & White people & 9.5 \\
\hline & Financial & 47 & Male & Black people & 10 \\
\hline & Information & 47 & Female & White people & 7 \\
\hline & Human Resources & 50 & Female & Black people & 11 \\
\hline & Operations & 53 & Male & White people & 2.5 \\
\hline & $\begin{array}{l}\text { Chief Executive } \\
\text { Officer }\end{array}$ & 53 & Male & White people & 9 \\
\hline \multirow[t]{6}{*}{$P$} & Acting MD & 57 & Male & White people & 12 \\
\hline & Operations (COO) & 36 & Male & Black people & 5 \\
\hline & $\begin{array}{l}\text { Acting Human } \\
\text { Resources }\end{array}$ & 59 & Male & White people & 7 \\
\hline & Operations (GM) & 36 & Male & White people & 3 \\
\hline & $\begin{array}{l}\text { Acting Internal } \\
\text { Auditor }\end{array}$ & 38 & Female & Black people & 1.5 \\
\hline & Risk & 45 & Male & Black people & 4 \\
\hline
\end{tabular}

Executive leaders were defined as being members of the executive committee in their company. The final samples are shown in Table 2.

\section{Data collection and recording}

The method of data collection was a semi-structured interview, the favoured method for IPA (Smith et al., 2009). The reason was that semi-structured interviews enable the collection of rich data because the interview guide only has a few open-ended questions, allowing the researcher to probe the participant's responses and explore novel areas raised by the participant in a flexible manner (Willig, 2008). This study formed part of a larger study (Bennett, 2015), in which the initial interview questions explored the executives' lived experience of uncertainty at a personal level and in their leadership role from the beginning of their period of organisational uncertainty up to the time of the interviews. Thereafter, to address the research objective of this paper, the following interview question was asked: When you reflect back on this experience of uncertainty that you have been through ... what did you learn and how did you develop from your experience of uncertainty - both personally and as a leader? Prompts were used to gather in-depth examples and to clarify the participants' meaning, such as What do you mean when you say you learned XYZ...? and Please give me a specific example of how you developed ABC. Each participant was interviewed in-depth by the researcher for approximately 2 hours. Each interview was recorded digitally and then transcribed verbatim. 


\section{Data analysis}

All the interviews for both samples (Company $\mathrm{R}$ and Company P) were completed before the data analysis commenced (Smith et al., 2009). In addition to analysis by the main researcher, a peer researcher, with prior experience of IPA, analysed the transcripts in each sample independently as a form of peer review (Smith, 2011) for each of the stages of the analysis. The analysis of each sample took an idiographic approach, based on textual analysis of the interview transcripts (Willig, 2008). The purpose of the initial stage of analysis was to identify and cluster the themes per case, starting with three executives. Thereafter, the analysis was integrated across these three executives to develop emerging key themes. These key themes were then applied to the analysis of the remaining three interviews in the sample, while being alert to possible new themes arising (Smith et al., 2009). Each level of analysis resulted in themes at a higher level of abstraction, which incorporated convergence and divergence across individuals within the sample. Finally, an integrative analysis of the key themes across Company $\mathrm{R}$ and Company P was conducted to address the research objective.

Strategies employed to ensure data quality and integrity: The quality of a study needs to be judged by criteria that align with the paradigm of the study (Smith et al., 2009; Willig, 2008; Yardley, 2008). Based on the interpretivist paradigm of this study, which accepts there will be different interpretations of a set of data, the key criterion for quality in IPA is 'to ensure that the current account is a credible one, not the only credible one' (Smith et al., 2009, p. 183). Two forms of complementary triangulation were used in the present study to foster completeness and enrich the data; that is, using two samples of executives from different organisational contexts of uncertainty (Hammersley, 2009; Yardley, 2008) and using a peer researcher to conduct independent analyses for dialogue purposes. Other key strategies were participant verification of their interview transcripts, grounding the findings in examples of verbatim extracts reflecting the participants' voices and ensuring that both convergence and divergence were captured within the themes.

\section{Reporting style}

With the combined sample (Company R and Company P), the IPA guidelines for writing up findings for larger samples (i.e., $n>8$ ) were adhered to (Smith, 2011; Smith et al., 2009). The findings focus on the recurring themes across both samples, based on being prevalent in at least 8 out of the 12 participants (i.e., present for 4 participants in each sample, or present for 3 and 5 participants in the respective samples). To preserve anonymity, as these executives worked together in their respective executive teams, pseudonyms were allocated to the 12 participants across both companies, using English male names for all participants. This measure, as suggested by Wiles, Crow, Heath and Charles (2006), assisted in concealing the identity of individuals while not distorting the findings in relation to the purpose of the study. In this article, extracts from two participants are provided in tables to illustrate the key themes. Additional participant extracts are included in the text to emphasise an essence of the theme and/or to illustrate variation within the theme.

\section{Findings}

In addressing the research objective, the participants reported the ways in which they had developed through their lived experience of uncertainty, lessons they learned in relation to challenges experienced in their leadership role during organisational uncertainty and what they found to be important for moving forward in their context of uncertainty. The three key themes resulting from the integrative analysis across Company R and Company P were (1) development of their mental frames, (2) the value of effective sense-making and (3) adopting certain approaches in their leadership role during uncertainty.

\section{Development of mental frames}

An over-arching finding was that all participants experienced personal growth through their lived experience of uncertainty, to a greater or lesser extent, which manifested in the development of their mental frames (Table 3). In particular, participants developed their sense of positive identity and their acceptance of uncertainty. Participants also acknowledged key dispositions that were crucial to them and which were further strengthened through their experience, those being resilience and optimism.

\section{Positive identity development}

Most participants had experienced personal uncertainty during the organisational uncertainty, which manifested as self-doubt or identity uncertainty. Thus, even though participants did not use identity as a term, most of them clearly developed their personal and/or leader identity through their lived experience of uncertainty, suggesting that positive identity development occurred, as conveyed by Colin and Bruce in Table 3, in their sense of increased confidence and personal agency for dealing with future uncertainty. There seemed to be a strengthening or updating of the participants' self-view mental frames, which in turn would influence their future approach in engaging with uncertainty.

TABLE 3: Development of mental frames.

\begin{tabular}{|c|c|c|}
\hline Sub-themes & Pseudonym & Participant quotes \\
\hline \multirow[t]{2}{*}{$\begin{array}{l}\text { Positive identity } \\
\text { development }\end{array}$} & Colin & $\begin{array}{l}\text { 'It made me stronger, you know, to deal with } \\
\text { these things [uncertainty] ...' }\end{array}$ \\
\hline & Bruce & $\begin{array}{l}\text { '... you can actually tabulate that I did this, I did } \\
\text { that, so it actually grows your portfolio ... Your } \\
\text { ability to have ridden the tide of uncertainty } \\
\text { promotes you to the next challenge'. }\end{array}$ \\
\hline \multirow[t]{2}{*}{$\begin{array}{l}\text { Acceptance of } \\
\text { uncertainty }\end{array}$} & Luke & $\begin{array}{l}\text { 'First of all uncertainty is a constant, it will } \\
\text { always be there. You're not going to wish it } \\
\text { away. So first again, make peace with that...' }\end{array}$ \\
\hline & Frank & $\begin{array}{l}\text { 'Then you make peace with the uncertainty. } \\
\text { You say, "You know what, I can't control that". }\end{array}$ \\
\hline \multirow{2}{*}{$\begin{array}{l}\text { Key dispositions: } \\
\text { resilience and } \\
\text { optimism }\end{array}$} & Evan & $\begin{array}{l}\text { 'So I became resilient ... I survived and that was } \\
\text { the way I survived'. }\end{array}$ \\
\hline & Allen & $\begin{array}{l}\text { 'So that [being optimistic] ... helped a lot, } \\
\text { personally and professionally'. }\end{array}$ \\
\hline
\end{tabular}


In contrast, positive identity development did not seem to occur to the same extent for two newcomers to their companies during the period of organisational uncertainty, who experienced intense personal uncertainty because of feeling excluded in their executive committees. This is illustrated in Dave's extract:

There were positive things ... on a personal level that I achieved ... but, you know, extremely frustrating because you are not only under-utilised, ... you're excluded.... We do talk ... but it's just when you have to actually get to a point of decision making ..., you know, the empowerment doesn't happen, it doesn't. [Dave]

While Dave experienced some personal growth through his experience, he did not portray clear positive identity development because of his attempts being thwarted by key stakeholders such as his boss and peers. Hence, identity development appeared not to be simply a result of the participants' own efforts, as it required reciprocity and affirmation from other key stakeholders in their contexts.

\section{Acceptance of uncertainty}

Most participants felt they had learned more about uncertainty as a result of their lived experience, including its pervasiveness in the world, and therefore the need to accept it, which then opened up opportunities for working more effectively with uncertainty. Extracts from Luke and Frank (Table 3) reflect how participants' mental frames relating to uncertainty developed. The realisation that the uncertainty, in most instances, could not be eliminated or reduced resulted in a shift in participants' worldview towards acceptance of uncertainty or making peace with uncertainty.

\section{Key dispositions: Resilience and optimism}

While most participants acknowledged that resilience and optimism were key dispositions crucial for persevering in and coping with the uncertainty, most felt they had strengthened these dispositions through their experience, as depicted by Evan and Allan in Table 3. These dispositions form part of the participants' self-view, which influences their making sense of uncertainty.

\section{The value of effective sense-making}

Most participants acknowledged the importance of making sense of their context of uncertainty and/or experienced uncertainty. They emphasised the need to search for more understanding or perspective, before responding or making decisions related to their felt uncertainty. More specifically, participants referred to certain factors (such as the need for time, being calm and the need to reflect) and/or having conversations with others, which facilitated more effective sense-making, seen in Table 4.

\section{Factors promoting effective sense-making: Time, being calm and reflection}

Some participants, such as Frank and Allan (Table 4), acknowledged their tendency to make quick decisions and learned that they need to consciously delay their decision making during uncertainty to allow themselves time to reflect, observe and assess, that is, to adopt more effective sense-making. Gavin and John (Table 4), referred to the need for being calm, or not emotional, either when reflecting on business challenges or when dealing with personal uncertainty. These participants implied that being calm enabled more effective sense-making, with the converse implied - that feelings of intense uncertainty might hinder effective sense-making. When participants described reflection, they used terms such as to 'step back' or 'stand back' from one's immediate context of uncertainty (as depicted by Frank and John in Table 3), suggesting the need for emotional distance and objectivity.

Of relevance to the subject of reflection, participants said they derived value from the research interview as it allowed them to reflect on their lived experience of uncertainty and how they had approached it. However, what was striking was that all participants, except for one, said they had not really reflected on or thought about the whole experience, because of time pressures, for example:

'... it's not something that you really get time to reflect on...' [John]

'You know, often you don't have time to ask yourself questions ... and it's not that easy to have a conversation with yourself.' [Ian]

TABLE 4: The value of effective sense-making.

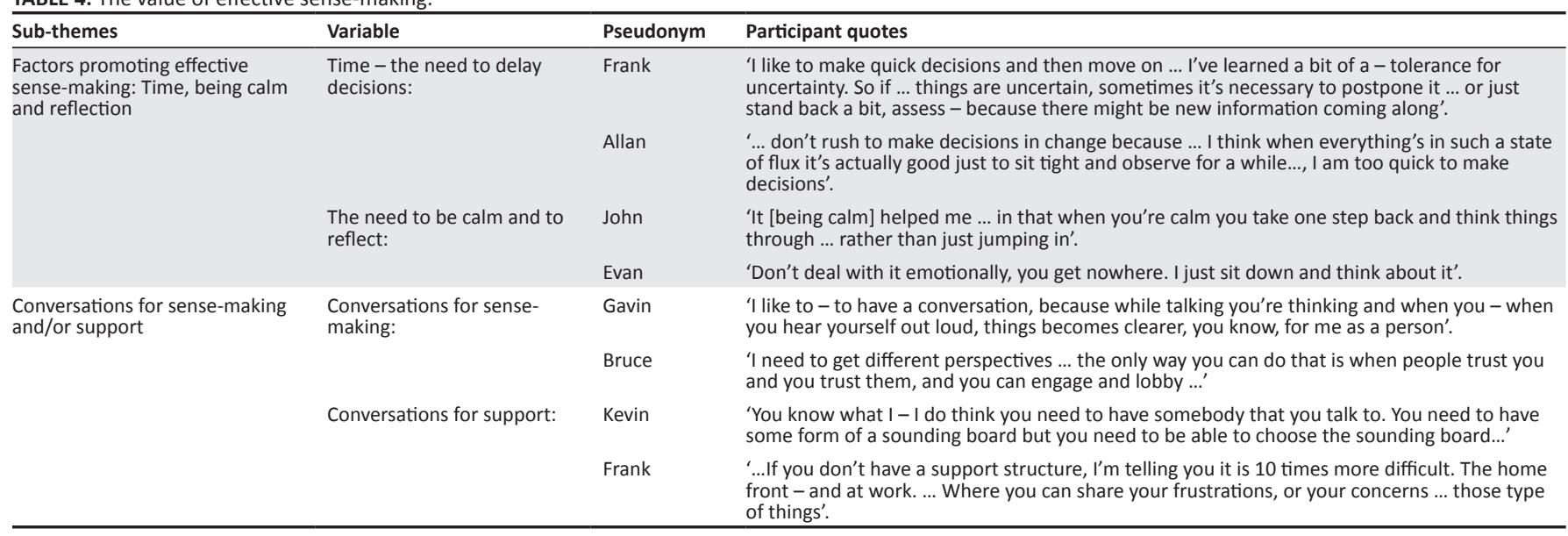


Some participants also suggested that reflection was not easy to do on their own, as in the case of Ian above. Taken together, time for sense-making and reflection, coupled with reflective ability and emotional regulation (or being calm), are all factors needed for fostering more effective sense-making.

\section{Conversations for sense-making and/or support}

Most participants reported on the value of having conversations with others for sense-making and/or as a form of support. Participants had a preference for sensemaking through conversations as this helped them to think through and make sense of their context of uncertainty (e.g., Gavin in Table 4) and/or they sought different perspectives by engaging with others, as for Bruce in Table 4 . The value of support from others during their lived experience of uncertainty was also acknowledged as being important; for example, Frank (Table 4) described his relationships and support structure as critically important. Whether engaging in conversations for sense-making and/or support, participants stressed the importance of seeking out people they trusted. Consequently, it seems that realising the value of sense-making, through conversations with others, led to the reinforcement or development of participants' mental frames relating to their 'view of others'.

\section{Leadership approach during uncertainty}

All participants had views on which leadership principles or approaches were of value to them when leading during the period of organisational uncertainty. Key themes, shown in Table 5, clustered around developing a leadership approach which engages others, the need for leadership focus and adaptability, adhering to certain communication principles and using political skill in dealing with key stakeholders.

\section{Leadership through engaging others}

Most participants acknowledged that, as a result of leading through organisational uncertainty, they had developed or re-affirmed aspects of their personal leadership approach, with an emphasis on involving and engaging their people more. As illustrated by Evan and Gavin in Table 5, they involved or engaged their people on the issues and way forward in their context of uncertainty. Therefore, this leadership approach reinforced and/or developed their mental frames in relation to 'views about others' as a leader.

\section{The importance of focus and adaptability}

The importance of focus was identified by most participants as essential for leadership when dealing with experienced complexity, which was a key challenge in their leadership role during organisational uncertainty. The focus was usually on what could be influenced or controlled in their context, through developing priorities and plans to align others' efforts and keep moving forward in the uncertainty, yet needing to adapt these plans, as captured by Luke and Frank (Table 5).
TABLE 5: Leadership approach during uncertainty.

\begin{tabular}{|c|c|c|}
\hline Sub-themes & Pseudonym & Participant quotes \\
\hline \multirow[t]{2}{*}{$\begin{array}{l}\text { Leadership through } \\
\text { engaging others }\end{array}$} & Evan & $\begin{array}{l}\text { 'There are certain fundamentals and you ... } \\
\text { follow through on that, you know .... And so } \\
\text { you have to get people engaged and - and } \\
\text { keep them involved'. }\end{array}$ \\
\hline & Gavin & $\begin{array}{l}\text { 'You know ... I find involving people, it makes } \\
\text { communication easier ... but also [asking } \\
\text { people] ... what can we do regarding this } \\
\text { uncertainty?' }\end{array}$ \\
\hline \multirow[t]{2}{*}{$\begin{array}{l}\text { The importance of } \\
\text { focus and } \\
\text { adaptability }\end{array}$} & Luke: & $\begin{array}{l}\text { 'Keep focussed ... because uncertainty can } \\
\text { move you off track.... Have a plan, execute it } \\
\text {... Look you have to adapt along the way, } \\
\text { make no mistake'. }\end{array}$ \\
\hline & Frank & $\begin{array}{l}\text { 'You make a conscious decision ... this I can do } \\
\text { something about ... let me make a plan ... how } \\
\text { I'm going to take this forward - and then you } \\
\text { make peace with that ... If the uncertainty } \\
\text { gives me new information, or new scenarios } \\
\text {... let's adapt the plan. Then you adapt'. }\end{array}$ \\
\hline \multirow[t]{2}{*}{$\begin{array}{l}\text { Communication } \\
\text { principles }\end{array}$} & Kevin & $\begin{array}{l}\text { '...you have to talk about it honestly and you } \\
\text { have to acknowledge it, and you have to try } \\
\text { to put it in context.... "You know what, I don't } \\
\text { know, but this is what I can tell you"'. }\end{array}$ \\
\hline & Bruce & $\begin{array}{l}\text { 'Telling them it's not going well ... but this is } \\
\text { what we are trying to do'. }\end{array}$ \\
\hline \multirow[t]{2}{*}{ Political skill } & Allan & $\begin{array}{l}\text { '... talking about choosing your battles, ... do it } \\
\text { a bit more calmly and more diplomatically...' }\end{array}$ \\
\hline & Peter & $\begin{array}{l}\text { '... how to ... pull different people in at } \\
\text { different times to - to have the desired } \\
\text { outcome. And I think I've ... learnt quite a bit } \\
\text { out of that.... You know, politics has got a }- \text { an } \\
\text { incorrect connotation ... it's more a case of } \\
\text { um - how do you bring the right people } \\
\text { together at the right time'. }\end{array}$ \\
\hline
\end{tabular}

\section{Communication principles}

Most participants in both companies appreciated the importance of communication in their leadership role during organisational uncertainty, in relation to managing the uncertainty of people in their contexts - particularly in the face of their own uncertainty, the essence of which is captured in the following extract:

... managing the uncertainty ... managing the request for information and for clarity ... and asking me to give people some idea of what was going on, in the face of my own uncertainty. [Allan]

Participants in both companies learned that the key principles for effective communication in times of uncertainty are being honest or realistic, while being positive, as captured by Kevin and Luke in Table 5.

\section{Political skill}

What was surprising was that only four participants identified political skill as an area of development, although most of them had experienced corporate politics as a key challenge in their leadership role during the period of organisational uncertainty. This discrepancy may have been because these four participants were in a more senior executive role, which required more political skill in interfacing with key stakeholders. The other participants, even if they developed their political skill, did not highlight it, possibly because of their negative perception of and discomfort with politics. While these four more senior executives (two from each company) acknowledged that they had developed their political skill through their experience, they also saw value in exercising improved political expertise. In the examples in Table 5, they referred to 
TABLE 6: Crucial components for developing a holistic capability for uncertainty.

\begin{tabular}{ll}
\hline Crucial component & Description of component \\
\hline A sense of positive identity & $\begin{array}{l}\text { A positive sense of self and leader identity, } \\
\text { fostering confidence and personal agency to } \\
\text { engage with uncertainty. }\end{array}$ \\
$\begin{array}{ll}\text { An acceptance of uncertainty } \\
\text { based on an appreciation of the pervasiveness } \\
\text { and flux of uncertainty in life. }\end{array}$ \\
$\begin{array}{ll}\text { Gaining new and different perspectives } \\
\text { through conversations with others. }\end{array}$ \\
$\begin{array}{ll}\text { Emotional regulation. } \\
\text { Challenging own assumptions and thinking } \\
\text { patterns. } \\
\text { Generating different and more plausible } \\
\text { interpretation/s of one's experienced } \\
\text { uncertainty and/or context of uncertainty. }\end{array}$ \\
$\begin{array}{l}\text { Allocating more time for reflection, with it } \\
\text { being more in-depth and critical. Willingness } \\
\text { and ability to learn from the experience of } \\
\text { uncertainty, and to apply this to future } \\
\text { experiences of uncertainty. }\end{array}$ \\
$\begin{array}{l}\text { Intra- and interpersonal frames and abilities } \\
\text { essential for leadership during organisational } \\
\text { uncertainty, with a focus on: dealing with } \\
\text { experienced complexity, leading others and } \\
\text { political skill for influencing key stakeholders. }\end{array}$ \\
\hline $\begin{array}{l}\text { Relevant leadership approach } \\
\text { during organisational uncertainty }\end{array}$
\end{tabular}

learning to be more diplomatic and using different approaches in dealing with and influencing key stakeholders.

\section{Integrative summary: A holistic capability for uncertainty}

An integrative analysis of the key findings and the components identified in the literature suggests that a holistic capability for uncertainty is composed of five crucial components as outlined in Table 6.

\section{Discussion}

The intent of the research objective was to understand what components potentially comprise a holistic capability for uncertainty, through understanding what was developed and/or learned through the executives' lived experience of uncertainty. The major finding was that the executives all seemed to develop some capability for uncertainty, to a greater or lesser extent, which could assist them with future experienced uncertainty, as illustrated in Figure 1.

The capability for uncertainty developed by the executives (Figure 1) comprised the following:

- The development of their mental frames, particularly their self-view through positive identity development, the strengthening of key dispositions (resilience and optimism), their shift in worldview towards acceptance of uncertainty and updating of their 'view of others' through their sense-making and leadership approaches (as depicted by the dashed arrows in Figure 1).

- An appreciation of factors that promote more effective sense-making, that is, making more time for sensemaking, the need for being calm and for more in-depth reflection to gain perspective and the importance of conversations for gaining different perspectives and emotional support.

- Leadership approach during uncertainty - with emphasis on adopting a leadership approach which engages others, the need for focus coupled with adaptability, adopting certain communication principles and political skill in dealing with key stakeholders.

There are a number of areas in which the findings of this research are consistent with previous studies or supported in the literature.

\section{Development of mental frames}

Most of the executives developed a sense of positive identity, manifesting in confidence and increased personal agency, through their lived experience of uncertainty. Identity uncertainty, relating to a devalued identity or self-doubt, was experienced by most of the executives. This experienced identity uncertainty appeared to be a key factor in initiating positive identity construction to repair, restore or further develop their identity, concurring with Dutton et al. (2010). In contrast, there were two newcomers who felt intense identity uncertainty because of exclusion by their colleagues, who did not seem to experience positive identity development. This seemed to be because of their identity development efforts being thwarted by key stakeholders, because identity construction is rooted in a social process of recognition and affirmation (Karp \& Helgo, 2009; Sinclair, 2011). These findings support authors who argue that positive identity construction is an important part of leader development and effectiveness, because a positive identity builds one's social resources (Dutton et al., 2010), giving access to other resources, by virtue of one's confidence, credibility and reputation as a leader (Day et al., 2009; Karp \& Helgo, 2009). Hence, the importance of a positive leader identity in developing one's capability for uncertainty is implied by these findings, in support of Bennis and Thomas (2002, p. 63), who associated a 'new or altered sense of identity' with adaptive capacity, developed through leaders' crucibles of experience.

While most executives acknowledged that resilience and optimism were key dispositions crucial for persevering in and coping with the uncertainty, they felt they had strengthened these dispositions (aspects of their self-view) through their experience, adding to their sense of positive identity. The necessity for and value of these type of dispositions, in dealing with adversity or crucibles of experience, is supported in the literature (Bennis \& Thomas, 2002; Lombardo \& Eichinger, 2002).

Most executives also reported a shift in their worldview towards acceptance of uncertainty or making peace with uncertainty. There is consensus that one's personal orientation towards uncertainty is an important factor in one's capability for uncertainty (Szeto \& Sorrentino, 2010; White \& Shullman, 2010). On the other hand, there is disagreement as to whether this orientation is a fixed personality trait or a malleable state, which one can develop (Smithson, 2008b). The latter view is supported by the present study's findings, namely, that one's personal orientation can be developed through experience, which concurs with the research findings of Bennis and Thomas (2002). 


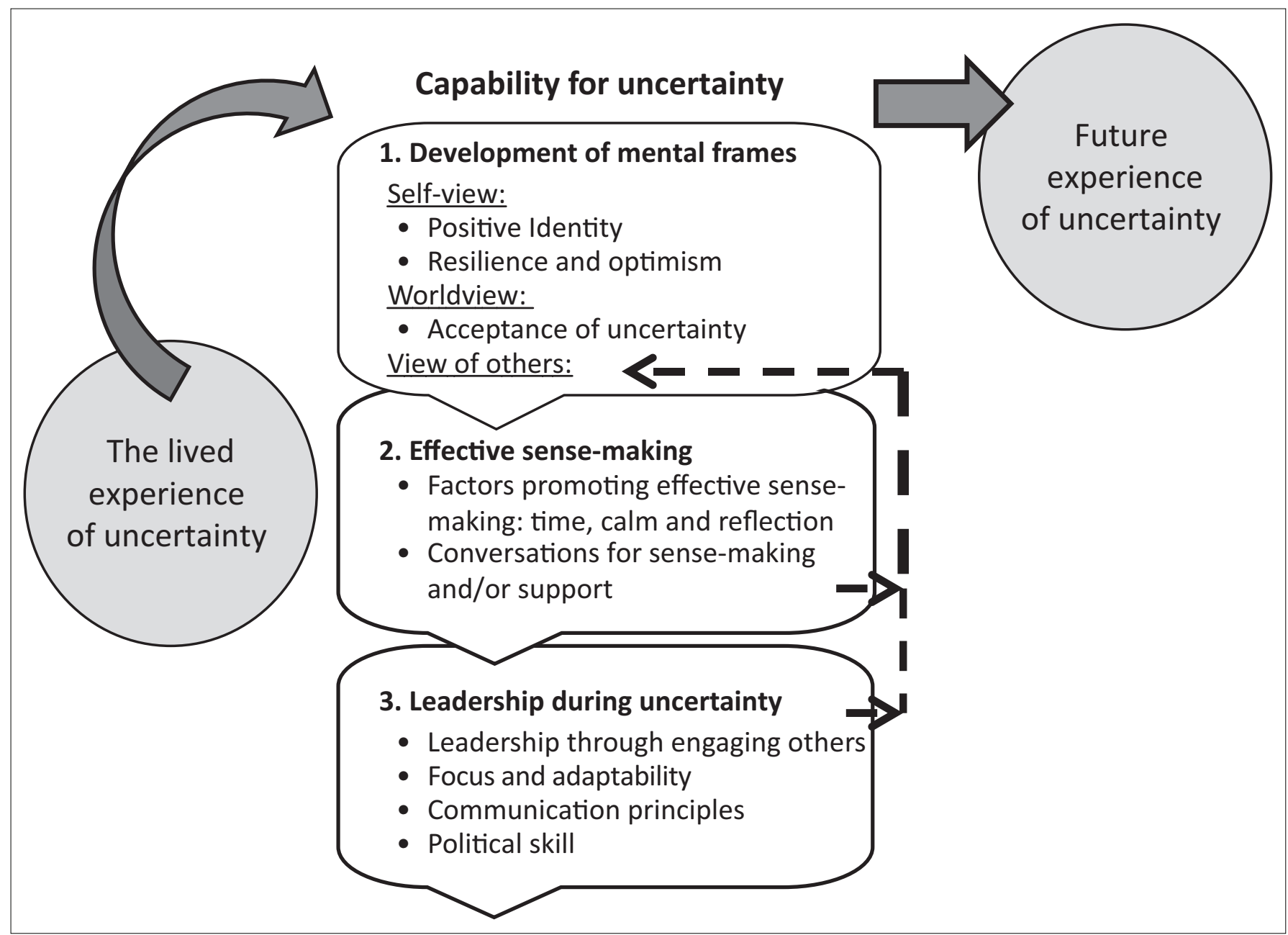

FIGURE 1: Executives' capability for uncertainty developed through lived experience.

\section{The value of effective sense-making}

Most executives realised that there were factors that helped or hindered their making sense of their uncertainty. Some reacted too quickly and therefore emphasised the need to delay one's response or decision making and to be calm and allow more time for sense-making. This finding supports authors who suggest that the discomfort of felt uncertainty often evokes a reactive threat response, which may motivate one to want to reduce the uncertainty by making a quick decision (Ancona, 2011; Van den Bos, 2009), particularly when the uncertainty is intensely felt (Maitlis et al., 2013). Indepth reflection did not seem to come easily for the executives (particularly doing it on their own), exacerbated by time pressures in their contexts, confirming the literature that leaders generally do not have time or make time for reflection (Day et al., 2009; DeRue \& Ashford, 2010a; Parry, 2003). The difficulty of in-depth critical reflection on one's own (which focusses on surfacing and questioning one's own assumptions and beliefs) has been acknowledged by Brockbank and McGill (2006), who argue that dialogue is essential for critical reflection, requiring emotional regulation or being calm. Furthermore, most of the executives had not reflected on their overall lived experience of uncertainty and their learning from it and valued the research interview as an opportunity to do so. This observation supports the consensus that the ability to learn from experience is an essential part of learning agility (DeRue \& Ashford, 2010a; Lombardo \& Eichinger, 2000; McCall, 2010) and is seemingly crucial for a capability for uncertainty.

Most executives also appreciated conversations (one-to-one and/or in teams) for sense-making and/or as a form of support, leading to the updating of their mental frames pertaining to 'view of others' (Figure 1). The value of sensemaking conversations was perceived in the different perspectives they gained, essential for effective sense-making (Ancona, 2011; Schwandt, 2005), rather than relying on their own mental frames. Supportive conversations, on the other hand, were valued as a form of coping and for reassurance (Malecki \& Demaray, 2003). However, individuals' choices about whom to converse with for sense-making and/or for support purposes were determined by their preferences, relationships and trust, aligning with Brashers (2001) views. Social support is considered to be an emotion-focussed coping mechanism adopted by individuals in contexts of uncertainty (Lazarus \& Folkman, 1984), as evidenced in the present study. Taken together, these findings suggest that effective sense-making coupled with learning agility (i.e., critical refection and learning from experience) seem to be crucial components of a capability for uncertainty. 


\section{Leadership approach during uncertainty}

Most executives had, as a result of leading through the uncertainty, developed aspects of their personal leadership approach, with an emphasis on involving and engaging their people on the issues and way forward in their context of uncertainty. This leadership approach concurs with an enabling leadership approach which authors, with a complex adaptive systems perspective, suggest is essential in increasingly turbulent times, to foster engagement for building adaptive capacity within organisations (Heifetz et al., 2009; Lane \& Down, 2010; Snowden \& Boone, 2007; Uhl-Bien et al., 2007).

In relation to their experienced complexity, most executives realised that they could not control or influence all the variables in their context, thus needing to focus on what could be influenced. Such focus was achieved largely through developing strategies, priorities and plans, while adapting their strategies or plans when new information emerged. This finding supports the literature in terms of the need to acknowledge that not everything can be controlled (Lane \& Down, 2010; Simpson, 2012) and the importance of focus and sense-giving, coupled with adaptability, for leadership during uncertainty (Goffee \& Jones, 2009; Heifetz et al., 2009; Lane \& Down, 2010).

Honest or realistic communication, while being positive, was perceived by most executives as being important during times of uncertainty. These communication principles highlighted by the executives tend to align with those espoused in the change leadership literature (e.g., Buchanan, 2008; Karp \& Helgo, 2008). The executives emphasised the need for coming to terms with their own personal uncertainty, as it would affect their communication with their people. The importance of leaders being genuine and able to regulate their emotions to convey a calm demeanour to people, in order to contain their anxiety, has been stressed in the literature (Day \& Power, 2009; Lane \& Down, 2010).

While most executives experienced corporate politics as a challenge in their leadership role, only four identified political skill as an area of development. It appears that these four executives developed their political skill because they were in a more senior role, which necessitated more political skill in interfacing with key stakeholders. The other participants possibly did not highlight development of political skill because of their negative perception of and discomfort with politics, which was emphasised by most participants as part of the challenge in having to navigate corporate politics. While the negative perceptions of politics are evident in the literature (Ashraf \& Iqbal, 2011; Buchanan, 2008), political skill is also seen as essential for leaders in organisations undergoing change (Ashraf \& Iqbal, 2011; Buchanan, 2008; Buchanan \& Badham, 2011). Political skill, however, is not emphasised in leadership development programmes (Buchanan \& Badham 2011).

\section{Practical implications}

The clarification of a holistic capability for uncertainty, and its five crucial components (Table 6), can assist organisational sponsors of leadership development in determining purposes for developing their executive and senior leaders' capability for uncertainty. It can also aid these sponsors in the choice and design of any interventions, including their content, aimed at developing the specific components of leaders' capability for uncertainty.

These findings specifically imply the need for developing leaders' critical reflective ability and the ability to learn from experience, which are central to the notion of a capability for uncertainty. While positive identity construction is emerging in leader development literature, it needs additional emphasis in leader development strategies and interventions. This is because a sense of positive identity is crucial for fostering the confidence and personal agency required for engaging with experienced uncertainty and/or contexts of uncertainty. Moreover, the leadership approach in dealing with the range of challenges that leaders experience in their roles during organisational change and uncertainty needs to be addressed. In particular, the development of political skill or intelligence requires more focus in leader development interventions, possibly framing this skill as 'positive influencing'. Many executives seem to perceive politics negatively, creating an aversion to developing their political expertise, while this is essential for the effective influencing of key stakeholders during organisational uncertainty.

Because capability for uncertainty is developed through experience, organisations need to target leader development interventions at identified 'crucibles of experienced uncertainty', such as transitions into new roles, on-boarding newcomers to the organisation, change-related projects and specific organisational changes. Organisations should intentionally use leader development approaches alongside these crucibles to harness real-time experiential learning; for example, action learning and executive coaching, towards more explicit development of components of a capability for uncertainty. Executive coaching has the added benefit of providing a safe, confidential learning space for executives who often find it difficult to share their vulnerability in relation to their experienced uncertainty.

\section{Limitations and recommendations}

The sample size in the study suggests that the findings are not generalisable. However, these findings do offer theoretical transferability (Smith et al., 2009) and may have relevance in similar contexts, to be gauged by the reader. The findings were subject to the researcher's interpretation, an inherent part of IPA. Several measures, aligned with the interpretivist paradigm, were adopted to ensure quality. The study was cross-sectional and retrospective. This study therefore did not capture data on how the executives' capability for uncertainty was enacted in their context, suggesting the need for a future longitudinal study to do this, utilising a smaller sample. 
Future research is recommended to focus on (1) developing and/or identifying tools for assessing the different components of a capability for uncertainty, (2) evaluating the development of such a capability, or different components thereof, in leaders through different development interventions, and in the longer term (3) to assess the impact of leaders' developed capability for uncertainty in their organisational context (e.g., designing questionnaires to assess the impact on employees' orientation to uncertainty and well-being during organisational uncertainty).

\section{Conclusion}

This study has clarified, and also refined the conceptualisation in the present literature, on what constitutes a holistic capability for uncertainty. Five crucial components were identified: a sense of positive identity, an acceptance of uncertainty, effective sense-making, learning agility and relevant leadership during organisational uncertainty. In these increasingly turbulent times, leaders need to develop their capability for uncertainty. By focussing on the five crucial components distilled from the executive leaders' lived experience of uncertainty in this study, organisations can design leader development interventions for the purpose of specifically developing leaders' capability for uncertainty.

\section{Acknowledgements Competing interests}

The authors declare that they have no financial or personal relationships which may have inappropriately influenced them in writing this article.

\section{Authors' contributions}

K.B. collected the data, conducted the literature review and interpreted the findings as part of her doctoral thesis. A.V. was the lead research supervisor and L.v.d.M. was the research co-supervisor. In addition, H.M. is acknowledged for assisting with the analysis of the data.

\section{References}

Akrivou, K., \& Bradbury-Huang, H. (2011). Executive catalysts: Predicting sustainable organizational performance amid complex demands. The Leadership Quarterly, 22, 995-1009. http://dx.doi.org/10.1016/j.leaqua.2011.07.019

Ancona, D. (2011). Sense-making: Framing and acting in the unknown. In S. Snook, N. Nohria \& R. Khrana (Eds.), The handbook for teaching leadership (pp. 3-19). Thousand Oaks, CA: Sage.

Argyris, C., \& Schon, D. (1996). Organisational learning: Theory, method and practice. Wokingham: Addison-Wesley.

Arkin, R.M., Oleson, K.C., \& Carroll, P.C. (Eds.). (2010). Handbook of the uncertain self. New York: Psychology Press.

Ashraf, F., \& Iqbal, M.Z. (2011). A research agenda on leaders' political intelligence for effective change management. African Journal of Business Management, 5(15) 6150-6158.

Avolio, B., \& Gardner, W. (2005). Authentic leadership development: Getting to the root of positive forms of leadership. Leadership Quarterly, 16, 315-338. http:// dx.doi.org/10.1016/j.leaqua.2005.03.001

Axon, L., Friedman, E., \& Jordan, K. (2015). Leading now: Critical capabilities for a complex world. (A Briefing Paper). Harvard Business Publishing. Retrieved November 8, 2015, from http://www. Harvardbusiness.org/sites/default/ files/19309_CL_LeadershipCap_Paper_July2015_O.pdf

Beautement, P., \& Broenner, C. (2011). Complexity demystified: A guide for practitioners. Retrieved July 10, 2014, from http://www.triarchypress.net/ complexity-demystified.html
Bennett, K. (2015). Making sense of and developing executive leaders' capability for uncertainty. Unpublished doctoral thesis. University of Johanesburg, Johannesburg, South Africa.

Bennis, W.G., \& Thomas, R.J. (2002). Crucibles of leadership. Harvard Business Review, $80,62-68$.

Brashers, D.E. (2001). Communication and uncertainty management. Journal of Communication, 51(3), 477-497. Retrieved May 5, 2011, from http://www. communication.illinois.edu/dbrasher/

Brockbank, A., \& McGill, I. (2006). Facilitating reflective learning through mentoring and coaching. London: Kogan Page.

Brown, R.B., \& McCartney, S. (2003). Lets have some capatence here. Education and Training, 46(1), 7-10. http://dx.doi.org/10.1108/00400910410518179

Bryman, A., \& Bell, E. (2003). Business research methods. Oxford: Oxford University Press.

Buchanan, D.A. (2008). You stab my back, I'll stab yours: Management experience and perceptions of organizational political behaviour. British Journal of Management, 19(1), 49-64. http://dx.doi.org/10.1111/j.1467-8551.2007.00533.x

Buchanan, D., \& Badham, R. (2011). Power, politics and organizational change. (Rev. 2nd edn.). London: Ashgate.

Buckle, L. (2009). What is the place of uncertainty in coaching purposes at senior levels in organisations? Unpublished master's thesis. University of Middlesex, London, UK.

Budner, S. (1962). Intolerance of ambiguity as a personality variable. Journal of Personality, 30, 29-50. http://dx.doi.org/10.1111/j.1467-6494.1962.tb02303.x

Bunker, K. (2010). A question of leadership. Leadership in Action, 29(6), 14-15. http:// dx.doi.org/10.1002/lia.1313

Cavanagh, M., \& Lane, D. (2012). Coaching psychology coming of age: The challenges we face in the messy world of complexity. International Coaching Psychology Review, 7(1), 75-90.

Day, A., \& Power, K. (2009). Developing leaders for a world of uncertainty, complexity and ambiguity. The Ashridge Journal, Winter, 20-25. Retrieved September 15 2010, from http://www.Ashridge.org.uk/360

Day, D.V. (2011). Leadership development. In A. Bryman, D. Collinson, K. Grint, B. Jackson, \& M. Uhl-Bien (Eds.), The Sage handbook of leadership (pp. 37-50). Thousand Oaks, CA: Sage.

Day, D.V., Harrison, M.M., \& Halpin, S.M. (2009). An integrative approach to leader development: Connecting adult development, identity and expertise. New York: Psychology Press.

DeRue, D.S., \& Ashford, S.J.(2010a). Power to the people: Where has the agency gone in leadership development? Industrial and Organizational Psychology, 3, 24-27. http://dx.doi.org/10.1111/j.1754-9434.2009.01191.x

DeRue, D. S., \& Myers, C. G. (2013). Leadership development: A review and agenda for future research. Oxford university press. Retrieved February 20, 2015, from http://dx.doi.org/10.1093/oxfordhb/9780199755615.013.040

Dutton, J.E., Roberts, L.M., \& Bednar, J. (2010). Pathways for positive identity construction at work: Four types of positive identity and the building of socia resources. Academy of Management Review, 35(2), 265-293. http://dx.doi. org/10.5465/AMR.2010.48463334

Gardner, G., Hase, S., Gardner, G., Dunn, S.V., \& Carryer, J. (2007). From competence to capability: A study of nurse practitioners in clinical practice. Journal of Clinical Nursing, 17, 250-258. http://dx.doi.org/10.1111/j.1365-2702.2006.01880.x

Goffee, R., \& Jones, G. (2009). The challenges facing leadership. Financial Times. Retrieved March 24, 2011, from http://www.Ft.com/intl/cms/s/fc

Greco, V., \& Roger, D. (2001). Coping with uncertainty: The construction and validation of a new measure. Personality and Individual Differences, 31, 519-534. http:// dx.doi.org/10.1016/S0191-8869(00)00156-2

Hammersley, M. (2009). Troubles with triangulation. In M.M. Bergman (Ed.), Advances in mixed methods research (pp. 22-36). Thousand Oaks: Sage.

Hannah, S., \& Avolio, B. (2010). Ready or not: How do we accelerate the developmental readiness of leaders? Journal of Organizational Behavior, 31, 1181-1187. http:// dx.doi.org/10.1002/job.675

Hase, S. (2002). Simplicity in complexity: Capable people and capable organisations need each other. Paper presented at Australian Vocational Education and Training Association Conference, Melbourne, VIC. Retrieved July 5, 2012, from http:// epubs@scu.edu.au

Heifetz, R., Grashow, A., \& Linsky, M. (2009). Leadership in a (permanent) crisis. Harvard Business Review, 87(7), 62-69.

Henning, E., van Rensburg, W., \& Smit, B. (2004). Finding your way in qualitative research. Pretoria: van Schaik.

Hogg, M.A. (2009). Managing self-uncertainty through group identification Psychological Inquiry: An International Journal for the Advancement of Psychological Theory, 20(4), 221-224. http://dx.doi.org/10.1080/10478400903333452

Jacques, E. (1989). Requisite organisation: A total system for effective managerial orgainsation and managerial leadership for the 21st century, Arlington, VA: Casin Hall \& Publishers.

Karp, T., \& Helgo, T.I.T. (2008). From change management to change leadership: Embracing chaotic change in public service organisations. Journal of Change Management, 8(1), 85-96. http://dx.doi.org/10.1080/14697010801937648

Karp, T., \& Helgo, T.I.T. (2009). Leadership as identity construction: The act of leading people in organisations. Journal of Management Development, 28(10), 880-896. $\mathrm{http}: / / \mathrm{dx}$.doi.org/10.1108/02621710911000659 
Kolb, D.A. (1984). Experiential learning: Experience as the source of learning and development. Englewood Cliffs, NJ: Prentice Hall.

Kurtz, C.F., \& Snowden, D.J. (2003). The new dynamics of strategy: Sense-making in a complex and complicated world. IBM Systems Journal, 42(3), 462-483. http:// dx.doi.org/10.1147/sj.423.0462

Lane, D.A., \& Down, M. (2010). The art of managing for the future: Leadership of turbulence. Management Decision, 48(4), 512-527. http://dx.doi.org/10.1108/ 00251741011041328

Lane, M.S., \& Klenke, K. (2004). The ambiguity tolerance interface: A modified social cognitive model for leading under uncertainty. Journal of Leadership \& Organizational Studies, 10(3), 69-81. http://dx.doi.org/10.1177/1071791904 01000306

Lazarus, R.S., \& Folkman, S. (1984). Stress, appraisal and coping. New York: Springer Publishing Company.

Lombardo, M.M., \& Eichinger, R.W. (2000). High potentials as high learners. Human Resource Management, 39, 321-330. http://dx.doi.org/10.1002/1099-050X (200024)39:4<321::AID-HRM4>3.0.CO;2-1

Lombardo, M.M., \& Eichinger, R.W. (2002). The CHOICES ARCHITECT ${ }^{\circledR}$ User's Manual. (2nd edn.). Minneapolis, MN: Lominger International.

Maitlis, S., \& Christianson, M. (2014). Sense-making in organizations: Taking stock and moving forward. The Academy of Management Annals, 8(1), 57-125. http:// dx.doi.org/10.1080/19416520.2014.873177

Maitlis, S., Vogus, T.J., \& Sonenshein, S. (2013). Sense-making and emotion in organizations. Organizational Psychology Review, 3(3), 222-247 . http://dx.doi. org/10.1177/2041386613489062

Malecki, C., \& Demaray, M. (2003). What type of support do they need? Investigating student adjustment as related to emotional, informational, appraisal and instrumental support. School Psychology Quarterly, 18(3), 231-252. http://dx.doi. org/10.1521/scpq.18.3.231.22576

McCall, M. (2010). Recasting leadership development. Industrial and Organizational Psychology, 3, 3-19. http://dx.doi.org/10.1111/j.1754-9434.2009.01189.x

McCall, M.W., Lombardo, M.M., \& Morrison, A.M. (1988). The lessons of experience: How successful executives develop on the job. Lexington, MA: Lexington Books.

Mezirow, J. (2001). Learning as transformation: Critical perspectives on a theory in progress. San Francisco, CA: Jossey-Bass.

Obolensky, N. (2010). Complex adaptive leadership: Embracing paradox and uncertainty. Surrey: Gower Publishing.

Parry, J. (2003). Making sense of executive sense-making: A phenomenological case study with methodological criticism. Journal of Health Organization and Management, 17, 240-263. http://dx.doi.org/10.1108/14777260310494771

Petrie, N. (2011). Future trends in leadership development. A white paper, Centre for Creative Leadership. Retrieved October 8, 2015, from http://insights.ccl.org/wpcontent/uploads/2015/04/futureTrends.pdf

Phelps, R., Hase, S., \& Ellis, A. (2005). Competency, complexity and computers: Exploring a new model for conceptualizing end-user education. British Journa of Educational Technology, 36(1), 67-84. http://dx.doi.org/10.1111/j.1467-8535. 2005.00439.x

Pringle, J., Drummond, J., McLafferty, E., \& Hendry, C. (2011). Interpretative phenomenological analysis: A discussion and critique. Nurse Researcher, 18(30) 20-24. http://dx.doi.org/10.7748/nr2011.04.18.3.20.c8459

Schwandt, D. (2005). When managers become philosophers: Integrating learning with sense-making. Academy of Management Learning \& Education, 4(2), 176-192. $\mathrm{http}: / / \mathrm{dx}$.doi.org/10.5465/AMLE.2005.17268565

Simpson, P. (2012). Complexity and change management: Analyzing church narratives Journal of Organizational Change Management, 25(2), 283-296. http://dx.doi. org/10.1108/09534811211213955
Sinclair, A. (2011). Being leaders: Identity and identity work in leadership. In A Bryman, D. Collinson, K. Grint, B. Jackson \& M. Uhl-Bien (Eds.), The Sage handbook of leadership (pp. 508-517). London: Sage.

Smerek, R. (2011). Sense-making and sensegiving: An exploratory study of the simultaneous 'being and learning' of new college and university presidents. Journal of Leadership \& Organisational Studies, 18, 80-94. http://dx.doi. org/10.1177/1548051810384268

Smith, J.A. (2011). Evaluating the contribution of interpretative phenomenological analysis. Health Psychology Review, 5(1), 9-27. http://dx.doi.org/10.1080/17437 199.2010.510659

Smith, J.A., Flowers, P., \& Larkin, M. (2009). Interpretative phenomenological analysis: Theory, method and research. London: Sage.

Smithson, M. (2008b). Psychology's ambivalent view of uncertainty. In G. Bammer \& M. Smithson (Eds.), Uncertainty and risk: Multidisiplinary perspectives (pp. 205-217) London: Earthscan.

Snowden, D.J., \& Boone, M.E. (2007). A leader's framework for decision making. Harvard Business Review, 85(11), 69-76.

Sorrentino, R.M., \& Roney, C.J.R. (2000). The uncertain mind: Individual differences in facing the unknown. Philadelphia, PA: Psychology Press.

Stacey, R.D. (1996). Strategic management \& organisational dynamics. London: Pitman.

Szeto, A.C.H., \& Sorrentino, R. M. (2010). Uncertainty orientation: Myths, truths, and the interface of motivation and cognition. In R.M. Arkin, K.wC. Oleson \& P.C. Carroll (Eds.), Handbook of the uncertain self (pp. 101-120). New York: Psychology Press.

Uhl-Bien, M., Marion, R., \& McKelvey, B. (2007). Complexity leadership theory: Shifting landscape from the industrial age to the knowledge era. The Leadership Quarterly, 18, 298-318. http://dx.doi.org/10.1016/j.leaqua.2007.04.002

Van den Bos, K. (2009). Making sense of life: The existential self trying to deal with personal uncertainty. Psycholgical Inquiry: An International Journal for the Advancement of Psychological Theory, 20(4), 197-217. http://dx.doi.org/10.1080/ 10478400903333411

Van den Bos, K., \& Lind, E.A. (2009). The social psychology of fairness and the regulation of personal uncertainty. In R.M. Arkin, K.C. Oleson \& P.J. Carroll (Eds.) Handbook of the uncertain self (pp. 122-141). New York: Psychology Press.

Weick, K.E. (1995). Sense-making in organizations. Thousand Oaks, CA: Sage.

Weick, K.E., Sutcliffe, K.M., \& Obstfeld, D. (2005). Organizing and the process of sensemaking. Organization Science, 16(4), 409-442. http://dx.doi.org/10.1287/orsc. 1050.01331

White, R.P., \& Shullman, R.L. (2010). Acceptance of uncertainty as an indicator of effective leadership. Consulting Psychology Journal: Practice and Research, 26(2), 94-104. http://dx.doi.org/10.1037/a0019991

Wiles, R., Crow,G., Heath, S., \& Charles, V. (2006). Anonymity and confidentiality. Paper presented at the ESRC Research Methods Festival, University of Oxford. University of Southampton, United Kingdom: ESRC National Centre for Research Methods. Retrieved May 10, 2013, from http://eprints.ncrm.ac.uk/423/1/0206 anonymity $\% 2520$ and $\% 2520$ confidentiality.pdf

Willig, C. (2008). Introducing qualitative research in psychology. (2nd edn.). Milton Keynes: Open University Press.

Woods, P., Gapp, R., King, M., \& Fisher, R. (2013). Exploring the complexity of managerial capability: Insights from the competence-capability debate. en Conference, Said Business School, Oxford University.Presented at the British Academy of Management Conference, 2013, Liverpool, United Kingdom.

Yardley, L. (2008). Demonstrating validity in qualitative psychology. In J.A. Smith (Ed.), Qualitative psychology: A practical guide to research methods (2nd edn., pp. 235-251). London: Sage. 